Performance appraisal of knowledge workers in $R \& D$ centers using gamification

Ehsan Abedi

Islamic Azad University, North Tehran Branch, Iran

Mehdi Shamizanjani

Fatemeh Sobhani Moghadam

Shahab Bazrafshan

University of Tehran, Iran

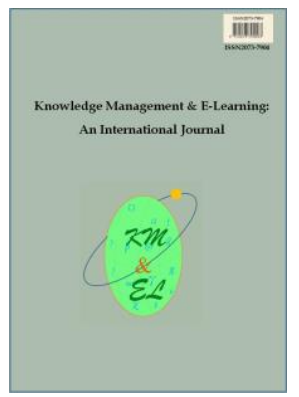

Knowledge Management \& E-Learning: An International Journal (KM\&EL) ISSN 2073-7904

Recommended citation:

Abedi, E., Shamizanjani, M., Moghadam, F. S., \& Bazrafshan, S. (2018).

Performance appraisal of knowledge workers in R\&D centers using gamification. Knowledge Management \& E-Learning, 10(2), 196-216. 


\title{
Performance appraisal of knowledge workers in R\&D centers using gamification
}

\author{
Ehsan Abedi* \\ Faculty of Management \\ Islamic Azad University, North Tehran Branch, Iran \\ E-mail: Ehsan_abedi@yahoo.com
}

\section{Mehdi Shamizanjani}

Faculty of Management

University of Tehran, Iran

E-mail: Shamizanjani@gmail.com

\section{Fatemeh Sobhani Moghadam}

Faculty of Management

University of Tehran, Iran

E-mail: Fatemeh.sobhanimoghadam@gmail.com

\section{Shahab Bazrafshan}

Faculty of Management

University of Tehran, Iran

E-mail: shahab.bzr@gmail.com

*Corresponding author

\begin{abstract}
In the knowledge-based economy, R\&D centers in service industries increasingly depend on the performance of knowledge workers to gain competitive advantage. Therefore, these centers must give careful consideration to the performance assessment and continuous improvement of knowledge workers using appropriate performance assessment systems and models. In this paper, a system was designed for the performance appraisal and ranking of knowledge workers in R\&D centers of banking industry using gamification approaches. The case study method was applied for the conceptual design of the system and the selected case was the R\&D center of Mellat bank, one of the Iranian leading private banks. Data collection was performed via semistructured interviews with 12 key participants of performance appraisal process which included vice president of research and development and 11 senior researchers as head of research groups of the center. As a result of data coding process for analyzing the qualitative data, a total of 23 metrics and three key performance indicators namely, research impact factor, knowledge impact factor and knowledge absorption factor were identified for the performance appraisal of knowledge workers. The designed system in this study can be used by $R \& D$ centers in banking industry for the performance appraisal and ranking of knowledge workers. The designed system provides a comprehensive and detailed set of metrics and KPIs for the performance appraisal of knowledge
\end{abstract}


workers in R\&D centers of banking industry.

Keywords: Performance appraisal; Knowledge workers; R\&D centers; Gamification; Banking industry

Biographical notes: Dr. Ehsan Abedi is Assistant Professor of Business Management in Islamic Azad University, North Tehran Branch, Iran. His current research interests include knowledge management and digital transformation.

Dr. Mehdi Shamizanjani is Associate Professor of IT Management at the Faculty of Management, University of Tehran, Iran. His current research interests include knowledge management, project management and digital transformation.

Shahab Bazrafshan holds a Master degree in IT Management from the University of Tehran where he specialized in Knowledge Management. He has been involved in Knowledge Management Implementation projects in banking industry since 2014 .

Fatemeh Sobhani Moghadam holds a Master degree in IT Management from the University of Tehran where she specialized in Knowledge Management. She has been involved in Knowledge Management Implementation projects in banking industry since 2014 .

\section{Introduction}

During the last two decades, a knowledge-based, fast-changing and technology-intensive economy has emerged in which investments in human resources, research and development and information technology have become essential in order to maintain an organization's competitive position and ensure its future viability (Ramezan, 2012). In the knowledge era, the most powerful tool of any organization is its knowledge from which sustainable competitive advantage can be derived (Suvarchala, 2013). Organizations' competitive edge almost wholly depends on how well they can manage and deploy their intangible assets including knowledge workers (Sanghani, 2009). Knowledge workers are key strategic resources in modern learning organizations; they are value creators and value adders whose major contributions come from their abilities to process and apply knowledge and information to completing essential tasks, making decisions and solving problems (McFarlane, 2008).

In a knowledge economy, there is an important relationship between issues related to the knowledge workers and the key performance indicators of organizations (Pan, Liu, \& Hawryszkiewycz, 2008; Adelstein, 2007). Since that knowledge workers make up twothirds of the labor force, the focus of strategic plans nowadays is to improve their efficiency (Ramirez \& Steudel, 2008). The performance of an individual knowledge worker drives the success of knowledge intensive organizations (Groen, Van de Belt, \& Wilderom, 2012; Miles, 2005). Knowledge workers' performance management is not an easy task and there is a need for pragmatic tools to support the managerial work (Palvalin, Vuolle, Jääskeläinen, Laihonen, \& Lönnqvist, 2015). Hence, organizations need an appropriate model to assess their knowledge workers' performance. The result of the assessment can play a critical role in providing appropriate practices for Knowledge 
workers' management (Wang, 2008). However, the nature of knowledge work is more complex; therefore, being more difficult to evaluate (Ramirez \& Steudel, 2008).

In the Knowledge Based Economy, Knowledge workers play a crucial role in maintaining the competitive advantage of R\&D centers. Many organizations view these centers as essential means for knowledge creation and gaining competitive advantage. In $R \& D$ centers, knowledge is a core asset and the only product (Ermine, 2010). Due to the rising costs of $R \& D$ and the increasing dependence of organizations on technology for competitive advantage, managers seek ways to improve effectiveness and efficiency of R\&D centers (Lee, Kim, \& Lee, 2011). Any R\&D center should continuously improve its performance, so it should apply the appropriate performance assessment model for collecting feedback and identifying the gaps which need to be improved (Khoshnevis, Tofigh, Ahmadvand, \& Keshvari, 2015). In an R\&D environment, performance is difficult to measure, and the outcome of R\&D activities often cannot be quantified in advance (Kahn \& McGourty, 2009). R\&D centers face unique challenges in managing performance as they generally support more open-ended creativity, longer-term visions, and more exploratory work. Metrics that will best assess performance will be specific to each R\&D center (Kahn \& McGourty, 2009). In recent years, R\&D in service industries has attracted a great deal of attention from both academia and industrial firms. However, the current research on R\&D performance measurement in the context of the service sector remains limited (Lee et al., 2011).

Although several researches have been conducted on productivity measurement of knowledge workers and performance measurement of R\&D centers (Laliene \& Sakalas, 2014; Ramezan, 2012; Takala, Suwansaranyu, \& Phusavat, 2006; Jyoti, Banwet, \& Deshmukh, 2008), there was almost no study on the issue of performance assessment of knowledge workers in R\&D centers of service industries. The primary goal of current performance assessment models is to evaluate to what extent an assigned job is done flawlessly by knowledge workers (Ghezel Arsalan, Heidary Dahooei, \& Zolghadr Shojai, 2014). Therefore, organizations in service industries need to develop a well-defined and comprehensive model or system for the performance appraisal of knowledge workers in their $R \& D$ centers.

In this regard, the adoption of the right performance appraisal technique or approach has been found to improve workers' performance and commitment (Femi, 2013). To develop an appropriate system for the performance appraisal of knowledge workers, researchers have proposed different assessment tools, techniques and approaches such as 540 degree feedback (Khoshnevis et al., 2015), appraisal interview at the end of the agreed period (Šikýr, Boras, \& Bakić-Tomić, 2008), management by objectives (Raj, 2007), a decision-making method (Patalas-Maliszewska, 2013), human behavior and performance approach (Nickols, 2012, 2014), Balanced Score Card (Yin, 2011; Bigliardi \& Dormio, 2010) and a compact questionnaire tool (Palvalin et al., 2015). Game-based assessment (GBA) is one of the modern techniques that can be used in employee assessment in order to yield desired outcomes (Heinzen, 2014). In this method, the concept of "gamification"-the incorporation of games and game elements (e.g., points, leaderboards, and badges) into non-game settings is adopted. (APQC, 2013; Deterding, Sicart, Nacke, O'Hara, \& Dixon, 2011). This paper aims to design a system for the performance appraisal of knowledge workers in the R\&D centers of banking industry using gamification techniques. 


\section{Literature review}

\subsection{Employee performance appraisal}

Employee performance appraisal is a process of evaluating the behavior of employees and providing feedback; normally including both the quantitative and qualitative aspects of job performances (Femi, 2013; Rao, 2005). In the organizational context, employee performance is usually defined as the extent to which an organizational member contributes to achieving the goals of the organization (Wankel \& Stoner, 2009). Employee performance can be approached not only from the perspective of task performance but also as the contextual performance (Koopmans et al., 2013; Kahya, 2008). Performance Appraisal is important because it helps in performance feedback, employee training, development decisions and career development (Aggarwal \& Thakur, 2013; Blstakova, 2010) and it provides a major potential for employee feedback that could link strongly to increasing motivation, an opportunity to clarify goals and achieve long-term individual performance and career development (Ghezel Arsalan et al., 2014). The main objectives of performance appraisal are to review and reward past performance, set goals for future performance and develop employees (Aggarwal \& Thakur, 2013; Sapra, 2012). Performance appraisal is often more related to behavior or actions of employees than the results of these actions (Koopmans et al., 2013). Performance appraisal has been synonymous with performance review, performance evaluation, performance assessment, performance measurement, employee evaluation, personnel review, staff assessment, service rating, etc. (Aggarwal \& Thakur, 2013; Kohli \& Deb, 2008). No other management process has as much influence over individuals' careers and work lives. Used well, performance appraisal is the most powerful instrument that organizations have to mobilize the energy of every employee of the enterprise toward the achievement of strategic goals. Performance appraisal can focus every person's attention on the organization's mission, vision, and values (Grote, 2011) and it may be seen as a viable organizational tool that may be used to motivate, direct and develop subordinates (Mustapha \& Daud, 2013).

The literature of human resource management presents a great variety of widely used and generic tools and practices (e.g. behaviorally anchored rating scales, competence frameworks and 360-degree feedback evaluation) aiming at performance appraisal of employees (Mann, Budworth, \& Ismaila, 2012; Fisher \& Sempik, 2005). For many organizations, the primary goal of an evaluation system is to improve individual and organizational performance. In creating and implementing an appraisal system, management must determine what the performance appraisal system will be used for and then decide on the process to implement the system. The methods chosen and the instruments used to implement these methods are crucial in determining whether the organization manages its performance successfully (Ahmed, Sultana, Paul, \& Azeem, 2013). So, a properly designed system can help achieve organizational objectives and enhance employee performance (Ahmed et al., 2013). It has been proved by many researches works that effective appraisal system is directly related to employee motivation and productivity. The effectiveness of an appraisal system depends on how well its purposes are understood, accepted and strived to be achieved by users (Mustapha \& Daud, 2013). A favorable performance appraisal would have positive effects on employee attitudes, behaviors and organizational efficiency (Cennamo \& Gardner, 2008; Salleh, Amin, Muda, \& Abdul Halim, 2013).

Performance appraisal was traditionally found mainly in manufacturing organizations, but service organizations increasingly engage in performance 
measurement systems as well (Radnor \& Barnes, 2007). Groen et al. (2012) have developed an enabling performance measurement system in a professional service organization. Such a system is perceived by employees as facilitating them in their work, rather than as primarily a control device for use by senior management (Wouters \& Wilderom, 2008) and it creates greater understanding among employees about how their tasks fit into the greater picture (Groen et al., 2012). According to above-mentioned statements, it is evident that properly designed and realized process of employees' appraisal is not only the necessary basis of successful employee performance management, but also provides valuable information for other human resource management functions (Blstakova, 2010).

\subsection{Performance appraisal of knowledge workers}

Today, business view is shifting from a product-centric to a knowledge-centric view (Sanghani, 2009). Work processes are very complicated and considerably knowledgeintensive in many industries and knowledge workers play a crucial role in maintaining the competitive advantage of organizations (Ghezel Arsalan et al., 2014). Knowledge work is defined as a job that consists of working with knowledge and performing activities like knowledge and information creation, finding, development and use (Turner $\&$ D'Art, 2008). The number and proportion of knowledge workers are increasing rapidly in comparison with those of manual workers (Ramirez \& Steudel, 2008).

Today's industry increasingly depends on the performance of knowledge workers (Ramirez \& Steudel, 2008) and the improvement of knowledge work performance is a key challenge of modern economy (Takala et al., 2006). Increasing the performance of knowledge work provides an opportunity for increasing profits by improving the overall process or product (Ramirez \& Steudel, 2008). Measurement information on knowledge work performance is needed both in daily managerial activities and in demonstrating the impacts of development initiatives. It is suggested in this context that the purpose of measurement should be oriented towards facilitating the employees' performance instead of formal control (Groen et al., 2012; Amir, Ahmad, \& Mohamad, 2010).

While the nature of knowledge work and the means to improve its performance (Davenport, Thomas, \& Cantrell, 2002) have been studied a lot, there are fewer studies on knowledge work performance measurement and knowledge workers performance assessment (Palvalin et al., 2015). Measurement of knowledge work performance is challenging due to many intangible performance drivers such as employee competencies and working atmosphere (Davenport, 2008), the intensive interaction between knowledge worker and customer (Gronroos \& Ojasalo, 2004) and the complex and intangible nature of service outputs (Lettice, Roth, \& Forstenlechner, 2006). More specific measurement challenges relate to the measurement of service impacts and customer value (Kujansivu \& Lonnqvist, 2009). Wake (2015) identified conditions that preclude measurement-based management and are likely to be observed in knowledge work including non-routine work in ill-defined or structured situations where output measurability and an understanding of the means-ends relationship of the work is not evident. Mclver and Wang (2016) have developed a new scale for measuring organizational knowledge involved in work based on the tacitness and learnability of work contexts. Hu, Wen, and Yan (2015) have proposed a theoretical framework integrating an analytic network process (ANP) with a balanced scorecard (BSC) to measure the performance of knowledge resources under value perspective. 
In most of the cases, performance assessment models have been developed for a specific type of knowledge workers and, therefore, not all knowledge workers can be compared to each other (Ramírez \& Nembhard, 2004). Yin (2011) has proposed a modified balanced scorecard model in order to assess the performance of knowledge workers properly which is mainly comprised of four perspectives: achievement, team work, communication, knowledge. Ghezel Arsalan et al. (2014) have introduced an applicable framework with specific and clearly defined steps which can be used by organizations to determine the value of knowledge workers based on their contribution to organizational value-added. Takala et al. (2006) proposed a structured framework, designated as the multi-dimension measurement process to measure the performance levels of white-collar workforce. There are also subjective measurement tools specifically aimed at performance measurement of knowledge workers (Kemppila \& Lonnqvist, 2003; Clements-Croome \& Kaluarachchi, 2000). These tools have been justified as easy and flexible to use in different work contexts and work profiles with the possibility to capture comprehensively the relevant intangible aspects of knowledge worker performance. However, subjectivity brings along its own problems. The reliability, comparability and credibility of the results can be questioned, sometimes leading to the avoidance of their usage (Jaaskelainen \& Laihonen, 2013).

According to Smith and Rupp (2004), performance-based rewards and understanding work-effects linkage would successfully engage knowledge workers. Knowledge workers enjoy the most positive work environment on all measures, which include perceptions of appraisal effectiveness (Mustapha \& Daud, 2013). High intensity of perceived performance appraisal effectiveness should result in extrinsic rewards such as higher salaries (Day \& Allen, 2004) or advancement (Allen, 2006) as well as intrinsic rewards such as self-satisfaction (Mustapha \& Daud, 2013). These rewards would enable knowledge workers to direct their energies in directions appropriate to their careers. With higher levels of career commitment, knowledge workers may make significant investments in their careers to pursue their high career goals, regardless of the setbacks (Mohamad \& Aizzat, 2006). They would also engage themselves with organizational training and job enrichment programs to attain new or higher skills and knowledge (Lobburi, 2012; Abdullah et al., 2012). Performance assessment can be a guideline for the development of knowledge workers (Mulhern \& Moiseyev, 2007) and organizations can assist knowledge workers acquire right competencies by providing them feedback (Ghezel Arsalan et al., 2014). So, organizations should apply the appropriate performance assessment model for collecting feedback from knowledge workers and identifying the gaps which need to be improved (Khoshnevis et al., 2015).

\subsection{Performance appraisal in $R \& D$ centers}

In the Knowledge Based Economy, R\&D centers play a crucial role in knowledge creation in order to build sustainable growth and competitive advantage for the organizations (Ermine, 2010). R\&D consists of "programs that focus on knowledge creation or its application to the creation of systems, methods, materials, or technologies". One of the biggest challenges of science-based companies is rooted in the integration of different functional areas of expertise and how they cope with the highly complex nature of the scientific knowledge base (Coradi, Heinzen, \& Boutellier, 2015). Knowledgeintensive organizations are widely seen as "people organizations" because their success relies strongly on highly qualified staff and the expertise of individuals (Von Nordenflycht, 2010). 
There are at least two specific aspects that have to be taken into account in management of knowledge-intensive organizations: the performance and well-being of individual knowledge worker and the ability to provide value for the customer (Jaaskelainen \& Laihonen, 2013). It is also well accepted that creativity-based organizations require flexible control mechanisms to support and encourage self-designed nature of knowledge work (Løwendahl, Revang, \& Fosstenlokken, 2001). Despite the fact that many knowledge-intensive organizations are fairly small, performance measurement can support their management, especially in facilitating employees rather than in formal control (Amir et al., 2010; Groen et al., 2012).

Organizations are seeking to show a good performance for their R\&D centers according to the necessity for high investment and the increasing importance of research and development for future competitiveness despite the fact that the performance evaluation of these centers and measuring their contribution in the success of relevant organization or community are very difficult (Loch \& Tapper, 2002). The high significance of human capital is a key distinctive feature of knowledge-intensive organizations (Von Nordenflycht, 2010). Therefore, performance measurement has to take this people aspect into account (Jaaskelainen \& Laihonen, 2013) and much of the discussion on the performance of knowledge work and knowledge-intensive organizations relate to an individual knowledge worker (Greene \& Myerson, 2011). The assessment of knowledge resources has two main managerial purposes, as follows: the governance of an organization's value creation dynamics and the communication of the value generated and/or incorporated by an organization (Lerro, Iacobone, \& Schiuma, 2012). In this type of environment, performance is generally harder to measure, available data is often less timely, and more unknowns exist. Traditional performance measurement activities apply clearly defined measures to evaluate performance outcomes but $R \& D$ centers face unique performance management challenges including difficulty in measuring performance and the many unknowns associated with R\&D efforts including lack of clarity of the initial scope of many projects (Kahn \& McGourty, 2009).

Organizations are increasingly using both quantitative and qualitative measures to manage performance and improve sustainable value of their R\&D centers (Kahn \& McGourty, 2009). However, the functionality and impacts of measurement are rarely discussed in the literature (Ittner, 2008). In a research with the aim at evaluating the performance in research organizations of India, Jyoti, Banwet, and Deshmukh (2008) have concluded that the performance evaluation for research and development organizations should be done based on the quantitative and qualitative outputs. Lazzarotti, Manzini, and Luca (2011) and Bigliardi and Dormino (2010) investigated different models and designed a model for performance evaluation in R\&D Organizations using the balanced scorecard approach. Wake (2015) found that the balanced scorecard can be used in knowledge-worker environments an important mechanism for ensuring that there is alignment between the strategic objectives of an organization and the work being undertaken. R\&D centers should be allowed flexibility to design and implement a performance management process aligned with their mission, goals, and objectives that can be systematically implemented with management support and active employee involvement to convey the true value of performance to the enterprise. So, R\&D centers must look introspectively to identify measures of performance to help achieve their goals (Kahn \& McGourty, 2009). 


\subsection{Performance appraisal using gamification approaches}

The concept of "gamification"-the incorporation of games and game elements (e.g., points, leaderboards, and badges) into non-game settings- has received a lot of attention in the business press recently (APQC, 2013; Huotari \& Hamari, 2012; Deterding et al., 2011). Gamification refers to the use of gaming-oriented mechanisms to address practical problems or to engage specific audience. The definition of any concept is always a difficult task; gamification is no exception. It is defined by different perspectives, sometimes in terms of behavior, sometimes in terms of human behavior, trends, as information treatment process, or, in terms of the learning situation (Koivisto \& Hamari, 2014).

Gamification has been used to enable attitude change and increase users' motivation in non-game situations (Robson, Plangger, Kietzmann, McCarthy, \& Pitt, 2015; Deterding et al., 2011). An effective gamification experience will motivate individuals' behavior changes in business settings (Robson et al., 2015). 'Gamified' experiences may focus on business processes like customer acquisition or business outcomes like employee sales (Robson et al., 2015). Game mechanics and psychology are used to drive a specific set of desired behaviors within a target group (APQC, 2013). Zichermann and Cunnigbam (2011) argue that "games are able to get people to take actions they don't always know they want to take, without the use of force, in a predictable way". Gamification can be used in employee assessment. The gamification approaches transform the way in which the assessment process was developed, providing adaptation tools and access to information resources for employees to demonstrate their learning and to take ownership of immediate feedback. The gamification approaches also provide more efficient, accurate and timely information for managers and policy makers in the organization (Darling-Hammond, 2010). Game-based assessment (GBA) is the application of principles of game design to measure performance when people are striving to perform at their best (Heinzen, 2014). While some approaches use the outcome of gamification like positioning on the leaderboard and number of badges for attained levels as criteria for assessment (O’Donovan, 2012), game elements can support assessment by influencing the learning task either dynamically for example by changing the context or having scripted events that are triggered by certain activities like reaching a certain milestone (Wood \& Reiners, 2013).

The formative assessment is the control function being performed throughout the course of employment, in order to check whether employees are reaching the objectives laid down. It is mainly through formative assessment that the employees know their mistakes and successes and find stimulus for performing their tasks. (Menezes \& de Bortolli, 2016). The gamification approaches have the potential to improve the way the formative assessment is conducted, involving employees in tasks that, if designed properly, will produce valuable information for the managers. Feedback mechanism also allows managers to detect and identify deficiencies. One of the main challenges is to create immersive gaming scenarios that can be used as assessment tasks, provided that they meet the quality criteria of assessment (for example, considerations of fairness, validity and reliability) (Menezes \& de Bortolli, 2016; Zapata-Rivera \& Bauer, 2012).

From a theoretical perspective, points provide feedback to the employees. Providing feedback regarding task performance is one of the most frequently applied psychological interventions. Points and other game-like elements provide information about success in the task. However, the gamification argument emphasizes the motivational aspect of game design elements over the possible cognitive or informational aspects. There are a number of motivational theoretical constructs that have been shown 
to mediate the effect of feedback and could be relevant to the point manipulation. It is not clear whether points would be perceived by employees as information about task performance (and then attention is more likely to be directed to the task) or as a form of prize for good performance (and then attention may be directed to the self). In particular, the concept of locus of attention is of interest in this respect. Properties of feedback can direct attention to the self or to the task, and attention to self has been shown to attenuate or even reverse the effects of feedback because it interferes with task performance. (Attali $\&$ Arieli-Attali, 2015). The difference between intrinsic and extrinsic motivators in employee assessment is another theoretical distinction that may shed light on the effect of game-like features. In other words, points and badges can be seen as extrinsic rewards for performing the task (Attali \& Arieli-Attali, 2015). Using gamification in employee assessment process is well-recognized in the research community but not yet explored to its full potential (Heinzen, 2014).

\section{Methodology}

This research was conducted using case study as the research strategy. Case study approach as research methodology is broadly recognized as a useful tool of holistic and in-depth problem analysis, allowing for contextual thinking, combing both qualitative and quantitative methods, shedding light on some specific features of the issues examined (Lechman, 2014; Easton, 2010; Fleetwood \& Ackroyd, 2004). Case studies constitute an important research tool in the field of management. In fact, case studies have been the source of some of the most important concepts in the field (Mariotto, Zanni, \& Moraes, 2014). The main strength of the case study approach is its ability to collect detailed information about a particular phenomenon or specific case (Stjelja, 2013).

The type of case study performed in this research was single case descriptive study. A single case study is usually conducted if the case is the representative/typical case (Yin, 2009; Eisenhardt \& Graebner, 2007). Descriptive case studies, as the name suggests, describe a phenomenon as well as the real-life situation in which it occurred (Stjelja, 2013; Tobin, 2010). The case selected for this research was the R\&D center of Mellat bank, one of the leading private banks of Iran. The center is responsible for conducting basic and applied researches required by the senior management in financial, economic and management fields to improve the quality of products and services. There are 11 research groups and a total of 93 researchers in this center working on different research projects.

In this case study, metrics used for the performance appraisal of knowledge workers in the R\&D center were investigated. Data collection was performed via semistructured interviews with 12 key participants of performance appraisal process which included vice president of research and development and 11 senior researchers as head of research groups of the center. The interviews lasted an average of 83 minutes and were all digitally recorded. Semi-structured interviews were based on the interview guide containing questions relating to the performance appraisal of knowledge workers. The interview guide consisted of six questions as below:

1. How do you define the performance appraisal of knowledge workers?

2. How do you conduct the performance appraisal process?

3. What types of performance metrics other than job-related ones do you use for the performance appraisal of knowledge workers? 
4. What other aspects of knowledge worker activities have been considered in the performance appraisal process? What mechanisms are in place to ensure that these aspects have been considered in the performance appraisal process?

5. What problems have you encountered in conducting the performance appraisal process? How do you deal with the problems?

6. What do you think should be done to improve the performance appraisal process?

In terms of the validity of the data, this was tested and confirmed via various approaches and methods. Triangulation of data was employed, and data were collected from multiple sources (key participants of performance appraisal process). The other approach was methodological triangulation in which a different data gathering technique was also used, i.e. organizational documents and reports related to the performance appraisal of knowledge workers in the R\&D center were also studied. For analyzing the qualitative data, data coding technique was applied. To validate the results, respondent validation or member checking method was used in this research in which study participants were invited to review the research findings in order to validate the researchers' analysis and interpretation of the data.

\section{Data analysis}

After conducting the interviews, interview data were transcribed and analyzed along with the data extracted from the organizational documents following a two-stage coding process namely, open coding and axial coding. In open coding stage, the data were fragmented, and key phrases were marked in order to extract useful properties as codes. As a result of the open coding process, 23 metrics for the performance appraisal of knowledge workers were identified which are shown in Table 1.

In axial coding stage, the identified codes were categorized based on the relationships among them and distinct concepts were defined for each category as axial codes. In this process, three main categories were defined as key performance indicators namely research impact factor, knowledge impact factor and knowledge absorption factor each containing specific quantitative metrics for assessing knowledge worker performance. The heads of research groups would also observe and assess knowledge worker's performance and give a rating to the knowledge worker on a 1-5 scale. This metric is considered in research impact factor.

After identifying the metrics and defining the key performance indicators, the analysis results were reviewed and confirmed by the study participants. They were also asked to assign weights to each metric. The average of weights assigned to each metric by the participants was calculated and set as its final weight. Based on the framework developed, the score for the three key performance indicators could be calculated for each knowledge worker as the weighted average of the metric quantities. Ranking of knowledge workers in each category is also possible based on the final points they have gained. Finally, according to gamification concepts, knowledge workers' ranks may be positioned on the leader board to display their performance. 
Table 1

The results of open coding

\begin{tabular}{|c|c|}
\hline No. & Codes \\
\hline 1 & The number of research projects (put into practice) that knowledge worker has participated in \\
\hline 2 & The average percentage of participation (amount of time spent) in research projects (put into practice) \\
\hline 3 & $\begin{array}{l}\text { The ratio of the number of research projects (put into practice) that knowledge worker has participated in to completed } \\
\text { research projects (in percentage) }\end{array}$ \\
\hline 4 & The number of successful research projects that knowledge worker has participated in \\
\hline 5 & The average percentage of participation (amount of time spent) in successful research projects \\
\hline 6 & $\begin{array}{l}\text { The ratio of the number of successful research projects (that knowledge worker has participated in) to completed } \\
\text { research projects (in percentage) }\end{array}$ \\
\hline 7 & The number of on-time research projects that knowledge worker has participated in \\
\hline 8 & The average percentage of participation (amount of time spent) in on-time research projects \\
\hline 9 & $\begin{array}{l}\text { The ratio of the number of on-time research projects (that knowledge worker has participated in) to completed research } \\
\text { projects (In percentage) }\end{array}$ \\
\hline 10 & The number of research reports presented to the senior managers \\
\hline 11 & The average percentage of participation in preparing the presented research reports \\
\hline 12 & The average score gained of the presented research reports \\
\hline 13 & The performance assessment score of knowledge worker (by head of the research group) \\
\hline 14 & The number of papers written by the knowledge worker \\
\hline 14.1 & Published in ISI-indexed journals \\
\hline 14.2 & Published in international conference proceedings \\
\hline 15 & The number of books published by the knowledge worker \\
\hline 16 & The number of memberships in scientific panels \\
\hline 17 & The number of experience presentations \\
\hline 18 & The number of workshop/educational seminar conduction (with at least 10 members) \\
\hline 19 & The number of awards received \\
\hline 20 & The man-hours of conference attendance \\
\hline 21 & The man-hours of training course attendance \\
\hline 22 & The man-hours of visiting reputable organizations and institutes \\
\hline 23 & The number of experiences (knowledge) acquired from the related community of experts and professionals \\
\hline
\end{tabular}

Based on the above-mentioned points, conceptual design of a system for the performance appraisal of knowledge workers in R\&D centers of banking industry was done. This system consists of two major parts namely Knowledge Profile and KPI. In the knowledge profile part, knowledge workers must complete the designed knowledge profile and update it at regular intervals. In the KPI part, metrics for the performance appraisal of knowledge workers are entered into the system and KPIs as system outputs are calculated considering the weights assigned to the metrics. The basic elements of this part are shown below in Table 2 .

Table 2

KPIs and Metrics for the performance appraisal of knowledge workers

\begin{tabular}{ccccc}
\hline \multicolumn{1}{c}{ No. } & KPIs & \multicolumn{1}{c}{ Metrics } & Weight \\
\hline & 1 & $\begin{array}{c}\text { Research } \\
\text { Impact }\end{array}$ & $\begin{array}{l}\text { The number of research projects (put into practice) } \\
\text { that a knowledge worker has participated in } \\
\text { The average percentage of participation (amount of }\end{array}$ & 0.30 \\
& 2 & Factor & $\begin{array}{l}\text { The and } \\
\text { time spent) in research projects (put into practice) }\end{array}$ &
\end{tabular}




\section{Knowledge}

16 Impact

17

18

19

\begin{tabular}{ccc} 
& 19 & \\
\hline & 20 & \\
& 21 & \\
& 22 & $\begin{array}{c}\text { Knowledge } \\
\text { Absorption } \\
\text { Factor }\end{array}$ \\
& &
\end{tabular}

The ratio of the number of research projects (put into practice) that a knowledge worker has participated in to completed research projects (In percentage)

The number of successful research projects that a knowledge worker has participated in

The average percentage of participation (amount of time spent) in successful research projects

The ratio of the number of successful research projects (that a knowledge worker has participated in) to completed research projects (In percentage)

The number of on-time research projects that a knowledge worker has participated in

The average percentage of participation (amount of time spent) in on-time research projects

The ratio of the number of on-time research projects (that a knowledge worker has participated in) to completed research projects (In percentage)

The number of research reports presented to the senior managers

The average percentage of participation in preparing the presented research reports

The average score gained of the presented research reports

The performance assessment score of knowledge worker (by head of the research group)

The number of papers written by the knowledge worker

Published in ISI-indexed journals

0.6

Published in international conference proceedings

The number of books published by the knowledge

worker

The number of memberships in scientific panels

0.12

The number of experience presentations

0.10

The number of workshop/educational seminar conduction (with at least 10 members)

The number of awards received

0.30

The man-hours of conference attendance

0.20

The man-hours of training course attendance

0.25

The man-hours of visiting reputable organizations and institutes

The number of experiences (knowledge) acquired from the related community of experts and professionals 
Knowledge workers' performance is assessed in the system comparing the knowledge workers' score for each key performance indicator with the highest and average scores at the group and center levels. Therefore, ranking of knowledge workers can be done via comparing the knowledge workers' scores to each other for each key performance indicator. The score comparison and ranking results for a knowledge worker 1 at the group level are displayed in the KPI part of the system as shown in Table 3 and Fig. 1. At six-month intervals, the knowledge worker who has gained rank 1 at the research group will be rewarded.

The score comparison and ranking results for knowledge workers at the center level are displayed in the KPI part of the system as shown in Table 4 and Fig. 2 which represent the score comparison and ranking results for the knowledge worker 1 at the center level. At six-month intervals, the knowledge workers who have gained rank 1-3 at the center level will be rewarded.

Table 3

The score comparison and ranking results for a knowledge worker 1 at the group level

\begin{tabular}{ccccc}
\hline KPIs & $\begin{array}{c}\text { Knowledge } \\
\text { Worker Score }\end{array}$ & $\begin{array}{c}\text { Highest Score at } \\
\text { the Research } \\
\text { Group }\end{array}$ & $\begin{array}{c}\text { Average Score at } \\
\text { the Research } \\
\text { Group }\end{array}$ & $\begin{array}{c}\text { Knowledge } \\
\text { Worker Rank at } \\
\text { the Research } \\
\text { Group (Out of 9) }\end{array}$ \\
\hline $\begin{array}{c}\text { Research } \\
\text { Impact } \\
\text { Factor }\end{array}$ & 15.60 & 17.10 & 17.20 & 3 \\
$\begin{array}{c}\text { Knowledge } \\
\text { Impact } \\
\text { Factor }\end{array}$ & 3.12 & 5.10 & 3.95 & 2 \\
$\begin{array}{c}\text { Knowledge } \\
\text { Absorption } \\
\text { Factor }\end{array}$ & 6.20 & 6.20 & & 2 \\
\hline
\end{tabular}

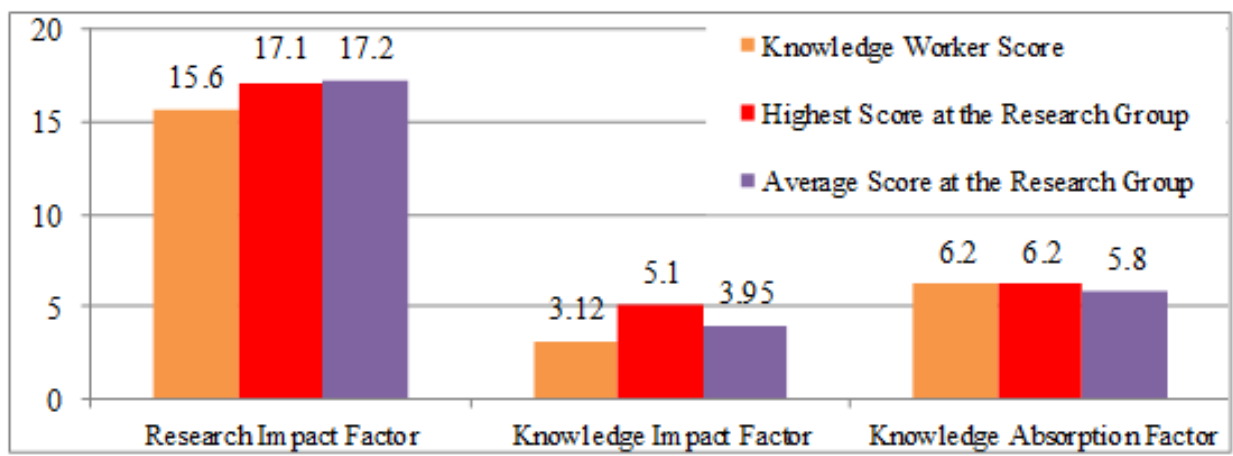

Fig. 1. The score comparison results for a knowledge worker 1 at the group level 
Table 4

The score comparison and ranking results for a knowledge worker 1 at the center level

\begin{tabular}{ccccc}
\hline KPIs & $\begin{array}{c}\text { Knowledge } \\
\text { Worker Score }\end{array}$ & $\begin{array}{c}\text { Highest Score at } \\
\text { the Center }\end{array}$ & $\begin{array}{c}\text { Average Score } \\
\text { at the Center }\end{array}$ & $\begin{array}{c}\text { Knowledge } \\
\text { Worker Rank at } \\
\text { the Center (Out } \\
\text { of 93) }\end{array}$ \\
\hline $\begin{array}{c}\text { Research } \\
\text { Impact } \\
\text { Factor }\end{array}$ & 15.60 & 18 & 17.20 & 14 \\
$\begin{array}{c}\text { Knowledge } \\
\text { Impact } \\
\text { Factor }\end{array}$ & 3.12 & 5.20 & 4.80 & 12 \\
$\begin{array}{c}\text { Knowledge } \\
\text { Absorption }\end{array}$ & 6.20 & & & 17 \\
Factor & 8 & 6.80 & \\
\hline
\end{tabular}

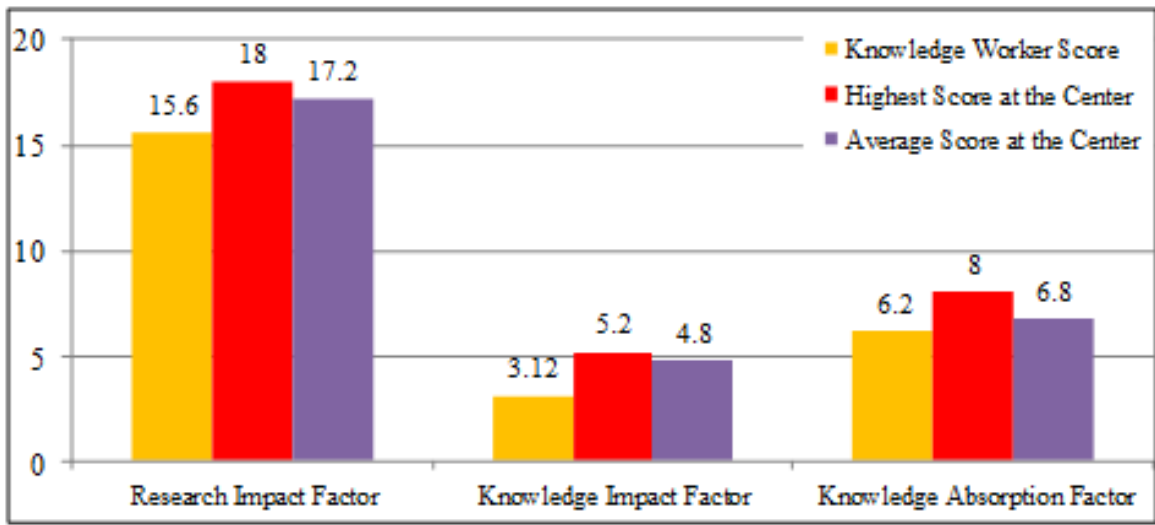

Fig. 2. The score comparison results for a knowledge worker 1 at the center level

For each research group, knowledge workers' scores for key performance indicators are compared with the average score at the group level and the results are displayed in the KPI part of the system as shown in Table 5 and Fig. 3 which represent the score comparison results of KPI 1 (Research Impact Factor) for research group 1.

Table 5

The score comparison results of a KPI 1 for a research group 1

\begin{tabular}{ccc}
\hline Research Group 1 & KPI 1 & Average Score \\
\hline Knowledge Worker 1 & 15.60 & \\
Knowledge Worker 2 & 12.20 & \\
Knowledge Worker 3 & 13.40 & 14.98 \\
Knowledge Worker 4 & 16.60 & \\
Knowledge Worker 5 & 17.10 & \\
\hline
\end{tabular}




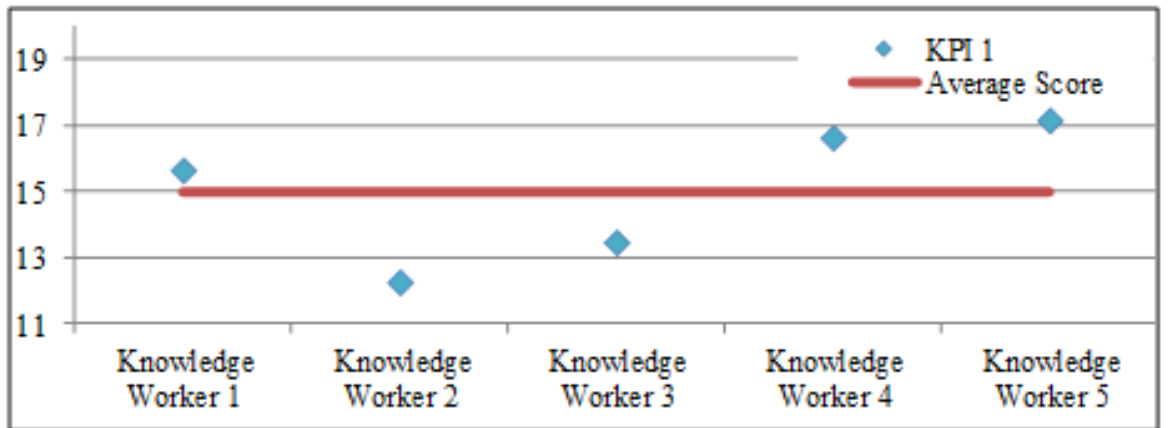

Fig. 3. The score comparison results of KPI 1 for research group 1

Research groups' performance is assessed in the system comparing the research groups' average score for each key performance indicator with the average score at the center level. The score comparison results of each key performance indicator for research groups are displayed in the KPI part of the system as shown in Table 6 and Fig. 4 which represent score comparison results of KPI 1 (Research Impact Factor) for research groups.

Table 6

The score comparison results of KPI 1 for research groups

\begin{tabular}{ccc}
\hline R\&D Center & Average Score of KPI 1 & Average Score at the Center Level \\
\hline Research Group 1 & 15.60 & \\
Research Group 2 & 14.50 & 15.10 \\
Research Group 3 & 16.10 & \\
Research Group 4 & 13.90 & \\
Research Group 5 & 15.40 & \\
\hline
\end{tabular}

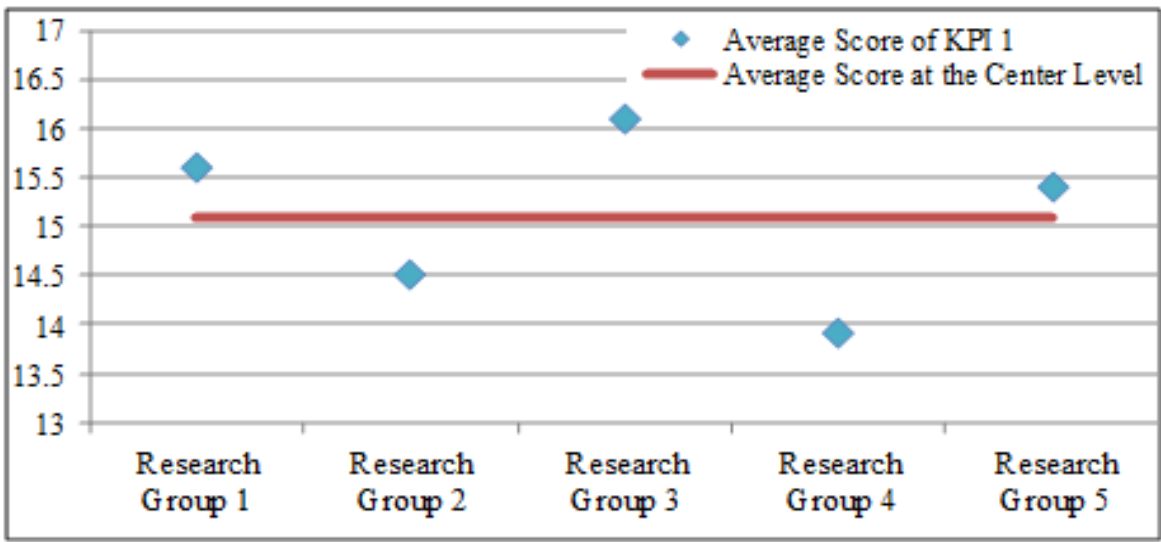

Fig. 4. The score comparison results of KPI 1 for research groups

Ranking of research groups is done via comparing the research groups' scores to each other for each key performance indicator. The ranking results are displayed in the KPI part of the system as shown in Table 7 which represents the ranking results for 
Research Group 1. At six-month intervals, the research group which has gained rank 1 at the center level will be rewarded.

Table 7

The ranking results for research group 1

\begin{tabular}{cccc}
\hline KPIs & $\begin{array}{c}\text { Research } \\
\text { Group Score }\end{array}$ & Average Score & $\begin{array}{c}\text { Research Group } \\
\text { Rank (Out of 11) }\end{array}$ \\
\hline $\begin{array}{c}\text { Research Impact Factor } \\
\text { Knowledge Impact } \\
\text { Factor }\end{array}$ & 15.60 & 15.10 & 2 \\
$\begin{array}{c}\text { Knowledge Absorption } \\
\text { Factor }\end{array}$ & 4.20 & 4.14 & 3 \\
\hline
\end{tabular}

\section{Conclusion}

In the knowledge-based economy, Knowledge workers play a crucial role in maintaining the competitive advantage of $R \& D$ centers. Therefore, these centers must give careful consideration to the performance assessment and continuous improvement of knowledge workers using appropriate performance assessment models, systems and techniques. Due to the growing importance of the service sector in the modern economy, in this research, a system was designed for the performance appraisal and ranking of knowledge workers in $R \& D$ centers of banking industry using gamification approaches. The case study method was applied for the conceptual design of the system and the selected case was the R\&D center of Mellat bank, one of the Iranian leading private banks.

In this system, performance appraisal of knowledge workers is done using three key performance indicators namely, research impact factor, knowledge impact factor and knowledge absorption factor. Research impact factor indicates the extent of knowledge workers participation in conducting research projects (successful projects, on-time projects and projects put to practice) and preparing research project reports. Performance assessment of knowledge workers by head of the research groups is also considered in this KPI. It is calculated based on the scores awarded to knowledge workers for 13 individual quantitative metrics considering the weights assigned to them. Knowledge impact factor indicates the extent of knowledge workers impact on the related community of experts and professionals in terms of knowledge and value creation (e.g. in the form of papers and books). It is calculated based on the scores awarded to knowledge workers for 6 individual metrics considering the weights assigned to them. Knowledge absorption factor indicates the extent of knowledge absorption from the related community of experts and professionals by knowledge workers. It is calculated based on the scores awarded to knowledge workers for four individual metrics considering the weights assigned to them. The methodology to conceptual design of the system is a novel addition to existing literature, as case study approach is used. Other innovative aspects of this research include designing the system for the performance appraisal of knowledge workers in $R \& D$ centers and in particular, $R \& D$ centers of banking industry. These centers can use the designed system for the performance appraisal of the knowledge workers.

For future studies, it is recommended that researchers focus on evaluating the efficiency of the designed system for the performance appraisal of knowledge workers in 
R\&D centers of banking industry. Further research could go deeper in the form of investigating the systems or approaches used for the performance appraisal of knowledge workers in $R \& D$ centers of other banks and $R \& D$ centers of other industries as well.

\section{References}

Abdullah, A., Bilau, A. A., Enegbuma, W. I., Ajagbe, A. M., Ali, K. N., \& Bustani, S. A. (2012). Small and medium sized construction firms job satisfaction and evaluation in Nigeria. International Journal of Social Science and Humanity, 2(1), 35-40.

Adelstein, J. (2007). Disconnecting knowledge from the knower: The knowledge worker as Icarus. Equal Opportunities International, 26(8), 853-871.

Aggarwal, A., \& Thakur, G. S. M. (2013). Techniques of performance appraisal - A review. International Journal of Engineering and Advanced Technology, 2(3), 617621.

Ahmed, I., Sultana, I., Paul, S. K., \& Azeem, A. (2013). Employee performance evaluation: A fuzzy approach. International Journal of Productivity and Performance Management, 62(7), 718-734.

Allen, T. D. (2006). Rewarding good citizens: The relationship between citizenship behavior, gender, and organizational rewards. Journal of Applied Social Psychology, 36(1), 120-143.

American Productivity and Quality Center (APQC). (2013). Gamification in knowledge management: An APQC overview. Retrieved from https://www.apqc.org/knowledgebase/documents/gamification-knowledge-management-apqc-overview

Amir, A. M., Ahmad, N. N. N., \& Mohamad, M. H. S. (2010). An investigation on PMS attributes in service organizations in Malaysia. International Journal of Productivity and Performance Management, 59(8), 734-756.

Attali, Y., \& Arieli-Attali, M. (2015). Gamification in assessment: Do points affect test performance? Computers \& Education, 83, 57-63.

Bigliardi, B., \& Ivo Dormio, A. (2010). A balanced scorecard approach for R\&D: Evidence from a case study. Facilities, 28(5/6), 278-289.

Blstakova, J. (2010). Employees' appraisal is an indicator of the quality of human resource management in organizations in Slovakia. Megatrend Review: The International Review of Applied Economics, 7(2), 79-99.

Cennamo, L., \& Gardner, D. (2008). Generational differences in work values, outcomes and person-organization values fit. Journal of Managerial Psychology, 23(8), 891906.

Clements-Croome, D., \& Kaluarachchi, Y. (2000), Assessment and measurement of productivity. In D. Clements-Croome (Ed.), Creating the Productive Workplace (pp. 129-166). London, UK: E \& FN Spon.

Coradi, A., Heinzen, H., \& Boutellier, R. (2015). Designing workspaces for crossfunctional knowledge-sharing in R \& D: The co-location pilot of Novartis. Journal of Knowledge Management, 19(2), 236-256.

Darling-Hammond, L. (2010). Teacher education and the American future. Journal of Teacher Education, 61, 35-47.

Davenport, T. H. (2008). Improving knowledge worker performance. In D. Pantaleo \& N. Pal (Eds.), From Strategy to Execution: Turing Accelerated Global Change into Opportunity (pp. 215-235). Berlin and Heidelberg: Springer.

Davenport, T. H., Thomas, R. J., \& Cantrell, S. (2002). The mysterious art and science of knowledge-worker performance. MIT Sloan Management Review, 44(1), 23-30.

Day, R., \& Allen, T. D. (2004). The relationship between career motivation and selfefficacy with protégé career success. Journal of Vocational Behavior, 64(1), 72-91. 
Deterding, S., Sicart, M., Nacke, L., O’Hara, K., \& Dixon, D. (2011). Gamification: Using game-design elements in non-gaming contexts. In Proceedings of the Annual Conference Extended Abstracts on Human Factors in Computing Systems (pp. 24252428). ACM.

Easton, G. (2010). Critical realism in case study research. Industrial Marketing Management, 39(1), 118-128.

Eisenhardt, K. M., \& Graebner, M. E. (2007), Theory building from cases: Opportunities and challenges. Academy of Management Journal, 50(1), 25-32.

Ermine, J. L. (2010). Methods and tools for knowledge management in research centers. EJKM: Electronic Journal of Knowledge Management, 8(3), 293-306.

Femi, A. F. (2013). Perception of performance appraisal and workers' performance in WEMA bank, headquarters, Lagos. Global Journal of Arts, Humanities and Social Sciences, 1(4), 89-101.

Fisher, C., \& Sempik, A. (2005). Performance management and performing management. In J. Leopold, L. Harris, \& T. Watson (Eds.), The Strategic Managing of Human Resources (pp. 178-210). Essex, UK: Pearson Education Limited.

Fleetwood, S., \& Ackroyd, S. (2004). Critical realist applications in organization and management studies. London, UK: Routledge.

Ghezel Arsalan, M. R., Heidary Dahooei, J., \& Zolghadr Shojai, A. (2014). A valuebased framework for the assessment of knowledge workers. VINE: The Journal of Information and Knowledge Management Systems, 44(2) ,295-318.

Greene, C., \& Myerson, J. (2011). Space for thought: Designing for knowledge workers. Facilities, 29(1/2), 19-30.

Groen, B. A. C., Van de Belt, M., \& Wilderom, C. P. M. (2012). Enabling performance measurement in a small professional service firm. International Journal of Productivity and Performance Management, 61(8), 839-862.

Gronroos, C., \& Ojasalo, K. (2004). Service productivity: Towards a conceptualization of the transformation of inputs into economic results in services. Journal of Business Research, 57(4), 414-423.

Grote, D. (2002). The performance appraisal question and answer book: A survival guide for managers. New York, NY: AMACOM.

Heinzen, T. E. (2014). Game-based assessment: Two practical justifications. In Proceedings of the KDD Annual Computer Science Conference.

$\mathrm{Hu}, \mathrm{Y} ., \mathrm{Wen}, \mathrm{J} ., \quad \&$ Yan, Y. (2015). Measuring the performance of knowledge resources using a value perspective: Integrating BSC and ANP. Journal of Knowledge Management, 19(6), 1250-1272.

Huotari, K., \& Hamari, J. (2012). Defining gamification: A service marketing perspective. In Proceedings of the 16th International Academic MindTrek Conference (pp. 17-22).

Ittner, C. D. (2008). Does measuring intangibles for management purposes improve performance? A review of the evidence. Accounting and Business Research, 38(3), 261-272.

Jaaskelainen, A., \& Laihonen, H. (2013). Overcoming the specific performance measurement challenges of knowledge-intensive organizations. International Journal of Productivity and Performance Management, 62(4), 350-363.

Jyoti, Banwet, D. K., \& Deshmukh, S. G. (2008). Evaluating performance of national $\mathrm{R} \& \mathrm{D}$ organizations using integrated DEA-AHP technique. International Journal of Productivity and Performance Management, 57(5), 370-388.

Kahn, C., \& McGourty, S. (2009). Performance management at R\&D organizations: Practices and metrics from case examples. Bedford, MA: The MITRE Corporation.

Kahya, E. (2008). The effects of job performance on effectiveness. International Journal of Industrial Ergonomics, 39(1), 96-104. 
Kemppila, S., \& Lonnqvist, A. (2003). Subjective productivity measurement. The Journal of American Academy of Business, 2(2), 531-537.

Khoshnevis, H., Tofigh, A. A, Ahmadvand, A. M., \& Keshvari, A. (2015). Providing an integrated model for evaluation of staff management and managers in project-based research organizations with a 540 degree feedback. Journal of Applied Environmental and Biological Sciences, 5(12s), 277-284.

Kohli, A. S., \& Deb, T. (2008). Performance management (1st ed.). Oxford, UK: Oxford University Press.

Koivisto, J., \& Hamari, J. (2014). Demographic differences in perceived benefits from gamification. Computers in Human Behavior, 35, 179-188.

Koopmans, L., Bernaards, C., Hildebrandt, V., van Buuren, S., van der Beek, A. J., \& de Vet, H. C. W. (2013). Development of an individual work performance questionnaire. International Journal of Productivity and Performance Management, 62(1), 6-28.

Kujansivu, P., \& Lonnqvist, A. (2009). Measuring the impacts of an IC development service: The case of the Pietari business campus. Electronic Journal of Knowledge Management, 7(4), 469-480.

Laliene, R., \& Sakalas, A. (2014). Conceptual structure of R\&D productivity assessment in public research organizations. Economics and Management, 19(1), 25-35.

Lazzarotti, V., Manzini, R., \& Luca, M. (2011). A model for R\&D performance measurement. International Journal of Production Economics, 134, 212-223

Lechman, E. (2014). Case study methodology: Few conceptual considerations. Przedsiębiorstwo we współczesnej gospodarce-teoria i praktyka, 4, 21-31.

Lee, Y., Kim, S., \& Lee, H. (2011). The impact of service R\&D on the performance of Korean information communication technology small and medium enterprises. Journal of Engineering and Technology Management, 28(1/2), 77-92.

Lerro, A., Iacobone, F. A., \& Schiuma, G. (2012). Knowledge assets assessment strategies: Organizational value, processes, approaches and evaluation architectures. Journal of Knowledge Management, 16(4), 563-575.

Lettice, F., Roth, N., \& Forstenlechner, I. (2006). Measuring knowledge in the new product development process. International Journal of Productivity and Performance Management, 55(3/4), 217-241.

Lobburi, P. (2012). The influence of organizational and social support on turnover intention in collectivist contexts. Journal of Applied Business Research, 28(1), 93104.

Loch, C. H., \& Tapper, U. A. S. (2002). Implementing a strategy-driven performance measurement system for an applied research group. Journal of Product Innovation Manage, 19(3), 185-198.

Løwendahl, B. R., Revang, O., \& Fosstenlokken, S. M. (2001). Knowledge and value creation in professional service firms. Human Relations, 54(7), 911-931.

Mann, S. L., Budworth, M. H., \& Ismaila, A. S. (2012). Ratings of counterproductive performance: The effect of source and rater behaviour. International Journal of Productivity and Performance Management, 61(2), 142-156.

Mariotto, F. L., Zanni, P. P., \& Moraes, G. H. S. (2014). What is the use of a single-case study in management research? Revista de Administração de Empresas, 54(4), 358369.

McFarlane, D. A. (2008). Effectively managing the 21st century knowledge worker. Journal of Knowledge Management Practice, 9(1), 3-7.

Mclver, D., \& Wang, X. (2016). Measuring knowledge in organizations: A knowledgein-practice approach. Journal of Knowledge Management, 20(4), 637-652.

Menezes, C. C. N., \& de Bortolli, R. (2016). Potential of gamification as assessment tool. Creative Education, 7, 561-566.

Miles, I. (2005). Knowledge intensive business services: Prospects and policies. 
Foresight, 7(6), 39-63.

Mohamad, A. H., \& Aizzat, M. N. (2006). Predicting turnover intention of hotel employees: The influence of employee development human resource management practices and trust in organization. Gadjah Mada International Journal of Business, $8(1), 21-42$.

Mulhern, F., \& Moiseyev, Y. (2007). Employee lifetime value: Measuring the long-term financial contribution of employees. Paper Presented at the Forum for people management andmeasurement performance improvement council.

Mustapha, M., \& Daud, M. (2013). Perceived performance appraisal effectiveness and turnover intention of knowledge workers: A conceptual model. Interdisciplinary Journal of contemporary Research in Business, 5(7), 11-38.

Nickols, F. (2012). HPT: The dawn of a new era. Performance Improvement, 51(3), 5-9.

Nickols, F. (2014). Knowledge workers: Fixing those "Broken" performance appraisals. Retrieved from http://www.nickols.us/FixingPerformanceAppraisals.pdf

O'Donovan, S. (2012). Gamification of the games course. Retrieved from http://pubs.cs.uct.ac.za/archive/00000771/01/Gamification_of_the_Games_Course.pd $\underline{\mathrm{f}}$

Palvalin, M., Vuolle, M., Jääskeläinen, A., Laihonen, H., \& Lönnqvist, A. (2015). SmartWoW - Constructing a tool for knowledge work performance analysis. International Journal of Productivity and Performance Management, 64(4), 479-498.

Pan, W., Liu, J., \& Hawryszkiewycz, I. (2008). A method for describing knowledge work processes. In Proceedings of the International Workshop on Advanced Information Systems for Enterprises (pp. 46-52): IWAISE 2008. IEEE.

Patalas-Maliszewska, J. (2013). Managing knowledge workers: Value assessment, methods, and application tools. Heidelberg: Springer.

Radnor, Z. J., \& Barnes, D. (2007). Historical analysis of performance measurement and management in operations management. International Journal of Productivity and Performance Management, 56(5/6), 384-396.

Raj, R. (2007). Corporate planning and strategic human resources management. Maharashtra: Nirali Prakashan.

Ramezan, M. (2012). Measuring the knowledge productivity: A comprehensive study of knowledge workers in Iranian industrial organizations. Education, Business and Society: Contemporary Middle Eastern Issues, 5(3), 200-212.

Ramírez, Y. W., \& Nembhard, D. A. (2004). Measuring knowledge worker productivity: A taxonomy. Journal of Intellectual Capital, 5(4), 602-628.

Ramirez, Y.W., \& Steudel, H. J. (2008). Measuring knowledge work: The knowledge work quantification framework. Journal of Intellectual Capital, 9(4), 564-584.

Rao, V. S. P. (2005). Human resource management: Text and cases (2nd ed.). New Delhi: Excel Books.

Robson, K., Plangger, K., Kietzmann, J. H., McCarthy, I., \& Pitt, L. (2015). Is it all a game? Understanding the principles of gamification. Business Horizons, 58(4), 411420.

Salleh, M., Amin, A., Muda, S., \& Abdul Halim, M. A. S. (2013). Fairness of performance appraisal and organizational commitment. Asian Social Science, 9(2), $121-128$.

Sanghani, P. (2009). Knowledge management implementation: Holistic framework based on Indian study. In Proceedings of the PACIS 2009.

Sapra, N. (2012). Current trends in performance appraisal. International Journal of Research in IT \& Management, 2(2), 1203-1211.

Šikýŕ, M., Boras, D., \& Bakić-Tomić, L. (2008). HRM practices in managing knowledge workers. In Proceedings of the ECNSI-2008 The 2nd International Conference on 
Advanced and systematic Research.

Smith, A. D., \& Rupp, W. T. (2004). Knowledge workers' perceptions of performance ratings. Journal of Workplace Learning, 16(3), 146-166.

Stjelja, M. (2013). The case study approach: Some theoretical, methodological and applied considerations. Edinburgh, Australia: Land Operations Division DSTO Defence Science and Technology Organisation.

Suvarchala, M. B. (2013). Knowledge management in commercial banks - A study of the state bank of India. International Journal in Multidisciplinary and Academic Research, 2(3): 11.

Takala, J., Suwansaranyu, U., \& Phusavat, K. (2006). A proposed white collar workforce performance measurement framework. Industrial Management \& Data Systems, 106(5), 644-662.

Tobin, R. (2010). Descriptive case study. In A. J. Mills, G. Durepos, \& E. Wiebe (Eds.), Encyclopedia of Case Study Research (pp. 289-290). Thousand Oaks, CA: SAGE Publications Inc.

Turner, T., \& D'art, D. (2008). Is there a new knowledge economy in Ireland? An analysis of recent occupational trends. International Journal of Manpower, 29(8), $700-714$.

Von Nordenflycht, A. (2010). What is a professional service firm? Toward a theory and taxonomy of knowledge-intensive firms. Academy of Management Review, $35(1), 155-174$.

Wake, N. J. (2015). The use of the balanced scorecard to measure knowledge work. International Journal of Productivity and Performance Management, 64(4), 590-602.

Wang, S. (2008). Study on the evaluation of knowledge worker value based on rough set theory. In Proceedings of the International Conference in Dalian of Wireless Communications, Networking and Mobile Computing. IEEE.

Wankel, C., \& Stoner, J. A. F. (2009). Management education for global sustainability. Charlotte, NC: Information Age Publishing.

Wood, L. C., \& Reiners, T. (2013). Game-based elements to upgrade bots to non-player characters in support of educators. In A. Hebbel-Seeger, T. Reiners, \& D. Schäfer (Eds.), Synthetic worlds: Emerging technologies in education and economics (pp. 257-277). Berlin: Springer.

Wouters, M., \& Wilderom, C. (2008). Developing performance measurement systems as enabling formalization: A longitudinal field study of a logistics department. Accounting, Organizations and Society, 33(4/5), 488-516.

Yin, Q. (2011). Performance model of knowledge workers based on balanced scorecard. In Proceedings of the IEEE 18th International Conference on Industrial Engineering and Engineering Management (IE\&EM) (Vol. 3, pp. 2143-2144)

Yin, R. K. (2009). Case study research: Design and methods. Thousand Oaks: SAGE.

Zapata-Rivera, D., \& Bauer, M. (2012). Exploring the role of games in educational assessment. In M. C. Mayrath, J. Clarke-Midura, D. H. Robinson, \& G. Schraw (Eds.), Technology-Based Assessments for Twenty-First-Century Skills: Theoretical and Practical Implications from Modern Research (pp. 147-169). Charlotte, NC: Information Age Publishing.

Zichermann, G., \& Cunningham, C. (2011). Gamification by design: Implementing game mechanics in web and mobile apps. Sebastopol, CA: O'Reilly Media. 